\title{
Transformational Leadership and Financial Performance: The Mediating Roles of Learning Orientation and Firm Innovativeness
}

\author{
Ploychompoo KITTIKUNCHOTIWUT ${ }^{1}$
}

Received: July 28, 2020 Revised: September 06, 2020 Accepted: September 10, 2020

\begin{abstract}
This study attempts to examine the relationships between transformational leadership, learning orientation, firm innovativeness, and financial performance. Specifically, the moderating effect of learning orientation and firm innovativeness. The data collected from 606 SMEs in Thailand were evaluated using the structural equation modeling, typifying that quantitative research. The results revealed that transformational leadership had a positive effect on learning orientation. Similarly, transformational leadership had a positive effect on firm innovativeness. Further, the study found that transformational leadership had a positive indirect effect on financial performance through the mediation of learning orientation. The results of the study found that transformational leadership had a positive indirect effect on financial performance through the mediation of firm innovativeness. Transformational leadership and learning orientation to improve innovation within the organization, including organizations and leaders among themselves. Especially, innovative firms inculcate ideals of promise to learning, open-mindedness, and shared vision. Furthermore, practitioners can use the findings of this study when they perform their role of leaders to challenge creativity and innovation among followers. Finally, those developments would influence a procedure of evidence procurement, evidence distribution and shared explanation that escalations equally individual and administrative effectiveness owing to its influence going on products.
\end{abstract}

Keywords: Transformational Leadership, Learning Orientation, Firm Innovativeness, Financial Performance, Small and Medium-sized Enterprises

JEL Classification Code: C54, D23, L25

\section{Introduction}

In the current era of globalization, there exists immense competition due to local and international competitors. For this reason, organizations are enforced to accept activities that are performance oriented and shows a central role in organizational expansion. Several support devices are approved by organizations to increase the human resource accessible to them. These devices were advanced at

${ }^{1}$ First Author and Corresponding Author. Assistant Professor, Mahasarakham Business School, Mahasarakham University, Thailand [Postal Address: Kantarawichai District, Muang City, Maha Sarakham Province, 44150, Thailand]

Email: ploychompoo.k@acc.msu.ac.th

() Copyright: The Author(s)

This is an Open Access article distributed under the terms of the Creative Commons Attribution Non-Commercial License (https://creativecommons.org/licenses/by-nc/4.0/) which permits unrestricted non-commercial use, distribution, and reproduction in any medium, provided the unrestricted non-commercial use,
original work is properly cited. organizational and operative level in which teams and employees of the organization were assumed learning opportunities, leadership support and empowerment as well (Yoon, Song, Lim, \& Joo, 2010; Mughal et al., 2019). In this concept, leadership is the mechanism of supporting or motivating a group of people to work towards achieving a common goal, where it can be leading employees and workers with a strategy to achieve a vision (Tajeddini, 2015).

Besides, a leader has different actions such as a pure vision nearby future, explicit and clear objectives that inspires assistants to set their goals and long-term vision. In this regard, leadership is the process of inspiration others especially influence the workers to raise their abilities for organizational success (Demir et al., 2019; Torlak \& Kuzey, 2019; Ali et al., 2020; Mohammed et al., 2020). Transformational leadership in selling with the data and perception of administration and reduced. Particularly about the resource and capital management, which results in superior intricacy of the challenges being targeted by people day afterward day, particularly in the bright of technical 
growth and the evidence insurrection (Budur, 2018; Budur et al., 2018). Furthermore, given the increasingly complex world of economic and social structures, especially in terms of the different uses of economic capital (Demir, 2019; Torlak et al., 2019) most leaders and entrepreneurs involved in expanding their businesses are kept abreast of inclusive vicissitudes in organization strategies and systems (Budur et al., 2019).

Learning is one of the utmost essential skills for inclusive businesses that makes it possible to scope business and cooperative goals. Currently, the capability to have quicker learning and the ability to transformation compared to an organization's competitors offers the base for supportable competition. As an outcome, today's administrations started to deed with a focus on learning to stay in the market and be successful in competition. Learning orientation is an administrative charge that is definite as the capability to produce, disseminate, and use of knowledge. It affects the evidence desirable and how it will be construed, evaluated, and shared (Calantone, Cavusgil \& Zhao, 2002). Learningoriented organizations are in a continuous pursuit for how people and administrations can learn organized. However, the effort has extended to comprise innovativeness as a mediating factor (Akgün et al., 2007; AragónCorrea et al., 2007; Keskin, 2006; Rhee et al., 2010). In particular, academics have initiate that learning orientation has an impact on performance and that innovativeness is a mediating influence that likewise straight distresses performance (Calantone et al., 2002; García-Morales et al., 2007). As well as, a great share of studies on learning orientation and firm innovativeness does not explanation for significant proportions of firm innovativeness.

The narrow operationalization of firm innovativeness that is as often as possible utilized prepares not explanation for measurements such as items, forms, marketplaces, and organization innovativeness. Aimed at instance, a business could be imaginative at progressing forms to decrease charges then not inventive by presenting unused items to unused marketplaces. In case the point is to construct unused information in a modern field, an essential operationalization of firm innovativeness container be invaluable. Nevertheless, these outcomes essential remain confirmed by an additional in-depth operationalization of the tenure founded on an extended antiquity of innovation inspection. Besides, previous academics have affirmed that a global and dependable degree for measuring innovativeness does not yet happen in the literature (Deshpande \& Farley, 2004). This scholarship pursues to fill this gap with the aid of utilizing an extensive meaning of firm innovativeness and a second-order construct appraised by using three firstorder indicators: product, process, and business system innovativeness.
In addition, a study by Llorens Montes et al., (2005) found that organizational learning effects both the organizational and practical innovation gap and performance, but they also found that transformation leadership has a direct effect on financial performance; organizational learning has a direct effect on performance. However, there is no clear evidence as to whether innovativeness and orientation towards learning play a part or full mediating role in the relationship between transformation leadership and financial performance. The mainstream of educations on the relationships amongst transformational leadership, learning orientation, firm innovativeness and financial performance have ignored the direct effect of learning orientation and firm innovativeness on financial performance (Hult et al., 2004; Rhee et al., 2010). Therefore, this study examines the relationships among transformational leadership, learning orientation, firm innovativeness and financial performance in the context of small and medium- sized enterprises (SMEs). The moderating effect of learning orientation and firm innovativeness will also be studied.

\section{Literature Review and Hypotheses Development}

Transformational leadership theory, according to Burns (1978), is composed of four components: (a) idealized influence, (b) inspiring motivation, (c) intellectual stimulation, and (d) individualized consideration (Bass, 1999, 2006; Kirkbride \& Kirkbride, 2006; Lim \& Ployhart, 2004; Avolio \& Gardner, 2005). Idealized influence states to leaders who, because of their unusual abilities and high principles of moral conduct, act as dense role replicas for their followers (Bass, 2006; Avolio \& Gardner, 2005). The leaders distribute a strong vision and mission for their organization to their followers, and in effect receive a great degree of support and hope from their groups (Bass, 2006; Avolio \& Gardner, 2005). The second component's inspiring encouragement concerns the potential of leaders to inspire followers to succeed above standards (Jain, 2015).

Hovering followers' understanding of the mission and purpose of the organization, empowering them in all substance and keeping them loyal to the association are the main sides of inspiring motivational transformational leadership (Kirkbride \& Kirkbride, 2006; Sarros \& Santora, 1995). Therefore, transformational leaders would perform in such a means that inspires and motivates groups (Das, 2017). Labors to be innovative and inventive by interrogative potentials, reframing complications, and impending new knowledge stimulate their supporters. There is still no general censure of the errors committed by individual representatives (Avolio \& Bass, 1995; Bass, 2006). Intellectual stimulation is often associated through the role of leaders in promoting 
imagination and ingenuity amongst groups (Metwally \& Elbishbishy, 2014).

Groups are expected to pursue new styles, and their proposals are not blamed for differing after the proposals of the leader (Bass, 2006). Individualized attention bandages the disruptive leadership practices of leaders who use this leadership style to take into account the needs of their followers and are equipped to promote the creation of positive organizational practices (Kirkbride \& Kirkbride, 2006; Sarros \& Santora, 1995). It in terms of needs and desires are recognized. The conduct of the chief calls for the understanding of human distinctions (Bass, 2006). Relevant transformational capabilities of leaders who are conventions for the use of the skills of a leader and the effective performance of the jobs of a leader (Das, 2017). In particular, in describing firm learning orientation, scholars used the resource-based view (RBV) primarily to highlight learning orientations as unique, important, inimitable, and idiosyncratic organizational tools that can work in harmony to build superior company efficiency and development (Barney, 1991; Lonial \& Carter, 2015).

An expansion of the Resource-Based View RBV viewpoint on fluid capacities conceptualizes learning orientations in terms of 'ability (1) to sense and form opportunities and challenges, (2) to grab opportunities, and (3) to sustain profitability by improving, integrating, preserving and, where possible, reconfiguring the intangible and tangible properties of the market enterprise.

\subsection{Transformational Leadership and Learning Orientation}

Transformational leadership refers to a creative leadership style in which leaders encourage individual focus, inspire followers, provide mental stimulation, assert idealized authority, stimulate development, and provide inspiring encouragement (Jung et al., 2003; Yukl, 1999). Earlier, Blanchard et al., (1993) added the concept of leadership through situational leadership that claimed that a single leadership style was working and dependent on the situation. Successful leadership will produce exceptional outcomes (Kouzes \& Posner, 2006). Because of its performance rates above further types of leadership, i.e. transactional and laissez-faire, transition leadership is generally recognized around the world (Bono \& Judge, 2004; McColl-Kennedy \& Anderson, 2002). Rasool et al. (2015) considered innovative leadership to be creative, utilizing self-deprecating humor, and encouraging to followers that eventually contribute to improving physician efficiency in the strength division. Besides, Bass et al., (2003) maintained that transformational leadership increases the feasibility of entity performance. Transformational leadership consuming motivational outfits canister pass effective organizational learning orientation to administrations (Geh, 2014), that can thrive organizational learning (Purushothaman, 2015).

Moreover, learning orientation is conceived as a fixed of ideals influencing the point to which a group is fulfilled through the concepts it has in routine (Argyris \& Schon, 1978), its rational replicas (De Geus, 1988), and its main reasons (Bettis \& Prahalad, 1995), which could or might not take needed their market-based basis. It effects the grade to which practices are possible to encourage the core competency of generative learning (Sinkula et al., 1997). It can likewise remain defined as a procedure of knowledge collection, distribution of knowledge and shared understanding that growths individual and organizational output unpaid to its direct influence on results (Kaya \& Patton, 2011). It is often seen as the grade to which companies proactively enquiry prevailing opinions and performs, and their effect on administrative performance (Argyris \& Schon, 1978). It stretches visions that have the possible to revolution behaviors (Huber, 1991; Slater \& Narver, 1995) through influencing on workers the continuous need to increase and spread their abilities and information (Kohli et al., 1998). Notably, learning orientation consists of four aspects, including learning engagement, mutual purpose, open-mindedness and intra-organizational information exchange (Calantone et al., 2002; Hurley \& Hult, 1998; Hult \& Ferrell, 1997; Hult, 1998; Sinkula et al., 1997; Moorman $\&$ Miner, 1998). Learning engagement is characterized as an administrative attribute, which is probable to promote a learning environment (Sinkula et al., 1997). Therefore, the research hypothesis is as follows:

H1: Transformational leadership has a positive influence on learning orientation.

\subsection{Transformational Leadership and Firm Innovativeness}

These academics deliberate the affiliation between firm innovativeness and transformation leadership in R\&D subdivisions as well as the offices of plan management. The properties of transformational leadership on firm innovativeness in administrations have generally remained a focus of attentiveness among researchers. Scholars in the literature have received specific descriptions of firm innovativeness. While some of these definitions reflect a company's ability to produce innovative products (Wang \& Ahmed, 2004). Others focus on innovative related cultures or behaviors reflecting an inclination or innovation capacity (Seda Mengü, 2015; Hurley \& Hult, 1998). Besides, Knowles, et al., (2008) presented a concept representing the product and behavioral engineering strengths of a company. 
Knowles et al., (2008) The scholars describe innovativeness as "the ability to produce and/or implement new goods, production process, and market structure" Wang \& Ahmed, (2004), have provided five dimensions of firm innovation in response to various conceptualizations of firm innovation in study streams which result in difficulties in comparing findings across studies. The five aspects are product innovation, business advancement, process innovation, organizational advancement and technical innovativeness. Work going on the causes of company performance and imagination takes established an extensive variety of influences after the separate level, such as the input style of a leader, to the collection equal, such as job arrangements and styles of contact, to the administrative equal, such as policy, function, community and environment (Damanpour, 1991). Our research attentions on the person equal, investigating the connection among the actions of transformational leadership and the expectations of leaders about the firm innovativeness of their employees. Nonetheless, additional way of understanding the linkage among transformation leadership and company creativity is founded on the basic idea essential transformational leadership theory that transformation leadership workers/followers view their jobs as more important and are thus additional self-engaged (Bono \& Judge, 2003). Therefore, in link with the research by McMurray et al. (2013) we expect transformational leadership actions to improve firm innovativeness. Therefore, the research hypothesis is as follows:

H2: Transformational leadership has a positive influence on firm innovativeness.

\subsection{Transformational Leadership and Financial Performance Mediated by Learning Orientation}

Study has demonstrated that transformational leadership (Sosik et al., 1998) and learning orientation (Janssen \& Van Yperen, 2004) are elements of workplace creativeness. In this research, learning orientation was identified such as a possible interface among transformational leadership and financial success for learning orientation allows workers to gain a thoughtful of their surroundings and strengthen their knowledge of effective tactics, encouraging them to effort vigorously and actively (Sujan et al., 1994). Transformational leaders offer dangerous support to their employees' learning and increase by modeling learning behavior, encouraging people to donate novel ideas, and safeguarding the distribution of knowledge that fosters creativity. In fact, transformational leaders view groups as individuals, display respect aimed at their particular challenges and working solutions, and offer incentives for growth. They assign flexibility and procedure their bigger expertise and ability to grow their groups through continuous learning phases that foster creativity (Avolio \& Gibbons, 1998; Bass, 1985; Dvir et al., 2002). Leaders can boost the imagination of followers through their abuse of the structure of organizational learning (Phipps et al., 2012). Transformational leadership orients followers through information sharing, strengthening employee goals, awareness, abilities, and learning expectations, which eventually leads to enhanced creativity.

We promote knowledge collection and dissemination, and mutual use of data that helps improve innovation. Transformational leaders are likewise clever to intrinsically influence their groups to learn novel ideas, concepts, and skills, apiece resulting in resourceful behavior (Joo \& Lim, 2009). Therefore, when linked with a learning orientation, transformative leadership assistances to improve the equal of creativeness as transformative leaders generate learningoriented environments done inspirational motivation, idealized influence, individual consideration and intellectual stimulation (Arendt, 2009), which encourages followers to accomplish extraordinary things, develop fair and equitable strategies. Therefore, the research hypothesis is as follows:

H3: Transformational leadership has a positive influence on financial performance mediated by learning orientation.

\subsection{Transformational Leadership and Financial Performance Mediated by Firm Innovativeness}

Leadership is a key component of corporate progress and performance from institutional and economic efficiency (Flanigan et al., 2017). Bearing in mind that leadership positively affects financial performance (Lee \& Lee, 2018). The Financial Analysis includes metrics related to the corporate plan (Westerfield, 2003; Parast et al., 2015). Measuring financial efficiency, in other words, can demonstrate how the strategy's execution leads to results. A financial outlook would produce good effects, affecting other outcomes (Kang et al., 2014). It is also important to monitor and balance the Financial Perspective with other non-financial perspectives. The transformational leadership's emphasis on maintaining partnerships with consumers, vendors, and stakeholders, or on product quality, must be matched with other financial metrics and positively affect them, which is also relevant to every other market metric (Kovach et al., 2015). In addition, Transformational leadership actions would improve financial results in line with McMurray et al. (2013) a study which showed that transformational leadership promoted creativity in the 
workplace. Since innate and prosocial incentive is correlated with transformational leadership, and since transformational leadership is correlated with creativity, mediation is likely to occur. In addition, we expect the association among transformational leadership and financial performance to remain driven through firm innovativeness. Therefore, the research hypothesis is as follows:

H4: Transformational leadership has a positive influence on financial performance mediated by firm innovativeness.

\section{Research Framework}

Based on the literature review, the framework for the study is illustrated in (Figure 1). The conceptual model of transformational leadership and financial performance: the mediating roles of learning orientation and firm innovativeness is presented in Figure 1.

\section{Research Method}

\subsection{Sample Characteristics and Data Collection}

This study surveys a quantitative methodological approach to test the suggested model by using a questionnaire to collect data. The survey instrument is a multi-item measure. All the variables were measured expending fivepoint Likert scales. The key informers were asked for the levels of arrangement with declarations of items ranging from 1 (strongly disagree) to 5 (strongly agree). The items were established from the prevailing scales of to each variable for this study explicitly. The hypothesized CFA measurement ideal consists of 16 measurement items and four latent constructs. The comprehensive measurement model is outlined in Figure 2. The SPSS version 16 and AMOS software programs were used to understand and evaluate the causal effects. Schumacker and Lomax, (1996) advised a process of situation suitable illustrative samples that is 10-20 samples per variable, depending on the complexity of the model. Processes aimed at improving the efficiency of companies and the effects of those procedures are crucial. We tested our hypothesis for this cause by focusing on the population for this study being the small and medium-sized enterprises (SMEs) in Thailand. API portal recruits research: www.sme.go.th/(2020). The research involves in particular commerce, operation, export, agriculture, food production, wearing clothing production, the export of other non-metallic mineral goods, manufacture of other metal resources like machinery and equipment, and other manufacturing. The researchers analyzed the information to prevent potential duplications arising from collaborator participation in the dataset. A mail investigation process was used for the collection of data via questionnaire. The principals included in this study were the directors or managers. Regarding the questionnaire's mailing, 18 samples became undeliverable since some businesses no longer existed or had moved to undisclosed areas. Deducting the undeliverable from the original 986 sent the correct post was 968 surveys receiving 610 responses. Of the surveys that were conducted and returned, only 606 were available. The effective response rate was approximately 62.60 percent. The response rate for a mail survey is deemed reasonable, deprived of a satisfactory follow-up process, and above 20 percent, rendering to Aaker, Kumar, and Day (2001).

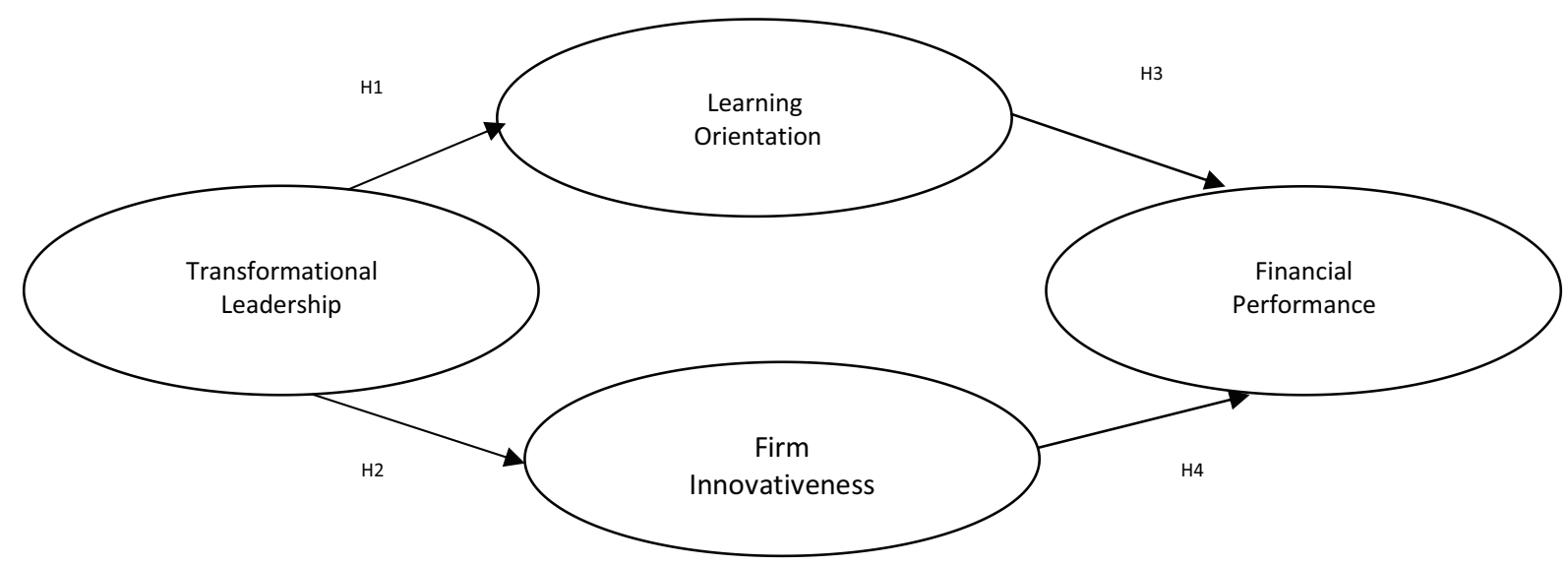

Figure 1: Framework of the Study 
Additionally, the use of a business sample based on a relatively homogeneous economic, industrial, political, sociocultural, technical, and legal area minimizes the influence of factors that cannot be regulated on qualitative research (Adler, 2015). We opted for this sense for several reasons. Small and medium-sized businesses (SMEs) are relatively well developed and have seen a marginally higher rate of growth relative to the economy as a whole in recent years. Besides that, small and medium-sized enterprises (SMEs) in Thailand are in a regional environment where the recognition of organizational researchers is comparatively low. Building on the knowledge of the core aspects of this research, prior interactions with interested CEOs and scholars, and new interviews with interested CEOs and academics. In fact, a bias test on non-response was conducted by comparing early and late responses. Business features include sector types, amount of capital expenditure, market time, and number of workers, and core informants who self-reported both buildings (Armstrong \& Overton, 1977). As for nonresponse bias, t-test statistical tests were performed, and; the results exhibited no significant differences. Therefore, a non-response bias is of no concern in this data.

\subsection{Measurement}

Besides, the first-order measures ranging from 1 (strongly disagreeable) to 5 (strongly agreed) were calculated using a five-point Likert scale. Transformational leadership will be assessed as a second-order construct by five first-order indicators: idealized influence, inspirational motivation, intellectual stimulation, and individualized consideration (Burns, 1978). Three first-order metrics were used to assess firm innovativeness as a secondorder construct: product innovation, process innovation, and business system innovation. The scale of company innovation was based on earlier studies (Avlonitis et al., 1994; Deshpandé et al., 1993; Knowles et al., 2008; Wang $\&$ Ahmed, 2004). Furthermore, learning orientation was restrained as a second-order construct and calculated by four first-order measures founded on Calantone et al. (2002) research and numerous previous studies (Galer \& van der Heijden, 1992; Hult \& Ferrell, 1997; Sinkula et al., 1997). The following four sub-dimensions are attention to learning, shared vision, openness to change, and sharing of knowledge intra-organizationally. Three objects are used to calculate each of the measurements. The three items with higher standard loadings based on Calantone et al. (2002) study will be selected. Consequently, four measures focused on Dess \& Robinson, (1984), will be used to assess financial performance. Such elements are revenue income, sales growth rates, asset after-tax returns, and overall profitability. The products will be assessed using a self-rated subjective scale, with respondents being asked to assess the facility level of their firm relative to that of their industry competitors.

\section{Results and Discussion}

There were three parts to the data analysis: 1) Analysis of Factor Loadings, Cronbach's Alpha Coefficients, Composite Reliability (CR), and Average Variance Extraced (AVE) for multiple item scales used this study in Table 1. Table 1 shows the all variables that have factor loading scores as between $0.797-0.894$ are greater than the 0.40 cut-off and are statistically significant (Nunnally \& Bernstein 1994). Additionally, Cronbach's alpha for all variables are shown between $0.843-0.890$ are greater than 0.70 (Nunnally \& Bernstein, 1994). Moreover, the Composite Reliability values were ranged between $0.791-0.961$ are greater than 0.70 (Hair et al., 2010). The Average Variance Extraced values were ranged between $0.586-0.860$ are greater than 0.50 (Hair et al., 2010). Therefore, all constructs of the validity and reliability of measurement can be applied for further analysis, and 2) Table 2 presents the descriptive statistics and correlation matrix for all variables. With respect to potential problems relating to multicollinearity, variance inflation factors (VIFs) were used to provide information on the extent to which nonorthogonality among independent variables inflates standard errors.

The VIFs range from well below the cutoff value of 10 as recommended by Neter, Wasserman, and Kutner (1985), means that the independent variables are not correlated with each other. Therefore, there are no substantial multicollinearity problems encountered in this study. 3) Analysis of the three variables of transformational leadership, the four variables of learning orientation, the four variables of firm innovativeness, and four variables of financial performance. Hypothesis testing was carried out using confirmatory factor analysis (CFA) to measure the validity of the model fit to the empirical data. The hypothesis model and empirical data were tested using structural equation modeling (SEM) which can lead to path analysis in order to be able to test the model and hypothesis (Wiratchai, 1999). Regarding the research framework, the model of confirmatory factor analysis and analysis of the structural equation model is shown in Figure 2. The result showed a good model fit with the empirical data within the expected level (Table 3). 
Table 1: Results of Measure Validation

\begin{tabular}{|c|c|c|c|c|c|}
\hline Construct & Indicator & Factor Loadings & Cronbach's Alpha & Composite Reliability & AVE \\
\hline $\begin{array}{l}\text { Transformational } \\
\text { Leadership (TL) }\end{array}$ & $\begin{array}{l}\text { TL1 } \\
\text { TL2 } \\
\text { TL3 } \\
\text { TL4 }\end{array}$ & $\begin{array}{l}0.797 \\
0.856 \\
0.859 \\
0.834\end{array}$ & 0.856 & 0.960 & 0.858 \\
\hline $\begin{array}{l}\text { Learning Orientation } \\
\text { (LO) }\end{array}$ & $\begin{array}{l}\text { LO1 } \\
\text { LO2 } \\
\text { LO3 } \\
\text { LO4 }\end{array}$ & $\begin{array}{l}0.807 \\
0.845 \\
0.851 \\
0.831 \\
\end{array}$ & 0.853 & 0.791 & 0.586 \\
\hline $\begin{array}{l}\text { Firm Innovativeness } \\
(\mathrm{FI})\end{array}$ & $\begin{array}{l}\mathrm{FI} 1 \\
\mathrm{Fl} 2 \\
\mathrm{FI3} \\
\mathrm{FI}\end{array}$ & $\begin{array}{l}0.803 \\
0.849 \\
0.831 \\
0.814\end{array}$ & 0.843 & 0.934 & 0.779 \\
\hline $\begin{array}{l}\text { Financial } \\
\text { Performance (FP) }\end{array}$ & $\begin{array}{l}\text { FP1 } \\
\text { FP2 } \\
\text { FP3 } \\
\text { FP4 }\end{array}$ & $\begin{array}{l}0.857 \\
0.894 \\
0.858 \\
0.867\end{array}$ & 0.890 & 0.961 & 0.860 \\
\hline
\end{tabular}

Table 2: Descriptive statistics and correlation matrix

\begin{tabular}{|l|c|c|c|c|c|c|}
\hline Variables & TL & LO & FI & FP & FA & FS \\
\hline Mean & 4.196 & 4.086 & 3.907 & 3.989 & 3.910 & 3.790 \\
\hline S.D. & 0.579 & 0.611 & 0.519 & 0.547 & 0.085 & 0.730 \\
\hline TL & 1 & & & & & \\
\hline LO & $0.659^{* *}$ & 1 & & & & \\
\hline FI & $0.409^{* *}$ & $0.580^{* *}$ & 1 & & & \\
\hline FP & $0.377^{* *}$ & $0.546^{* *}$ & $0.695^{* *}$ & 1 & & \\
\hline FA & $0.253^{* *}$ & $0.418^{* *}$ & $0.426^{* *}$ & $0.564^{* *}$ & 1 & \\
\hline FS & $0.199^{* *}$ & $0.349^{* *}$ & $0.401^{* *}$ & $0.553^{* *}$ & $0.499^{* *}$ & 1 \\
\hline
\end{tabular}

${ }^{* * *} p<0.01,{ }^{* *} p<0.05,{ }^{*} p<0.10$

Table 3: Statistics from Fitting Evaluation

\begin{tabular}{|l|l|c|}
\hline \multicolumn{1}{|c|}{ Goodness-of-Fit Measure } & \multicolumn{1}{|c|}{ Recommended Value } & Structural Model (result) \\
\hline CMIN/DF & $2.0-5.0$ (Diamantopoulos \& Siguaw, 2000) & 3.870 \\
\hline GFI & $\geq 0.900$ (Diamantopoulos \& Siguaw, 2000) & 0.930 \\
\hline AGFI & $\geq 0.900$ (Diamantopoulos \& Siguaw, 2000) & 0.905 \\
\hline CFI & $\geq 0.900$ (Kelloway, 2015) & 0.972 \\
\hline NFI & $\geq 0.900$ (Schumacker \& Lomax, 2010) & 0.962 \\
\hline RMSEA & $\leq 0.080$ (Schumacker \& Lomax, 2010) & 0.069 \\
\hline TLI & $\geq 0.900$ (Schumacker \& Lomax, 2010) & 0.975 \\
\hline RMR & $\leq 0.050$ (Diamantopoulos \& Siguaw, 2000) & 0.966 \\
\hline
\end{tabular}




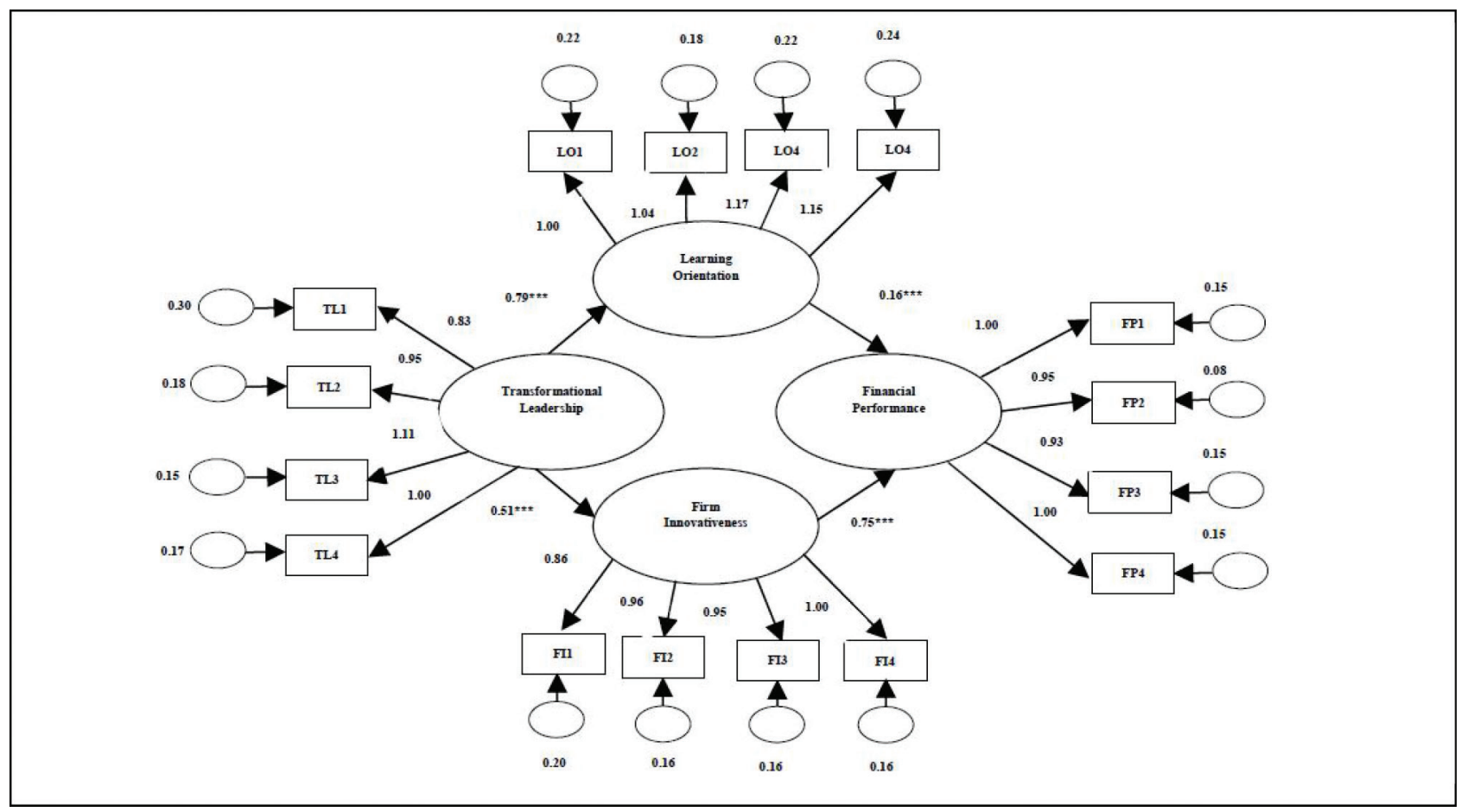

Figure 2: The Structural Equation Model

Table 4: Direct and Indirect Effects of Variables

\begin{tabular}{|l|c|c|c|c|c|}
\hline Hypothesis & Relationship & Std Beta & Std Error & t-value & Conclusion \\
\hline $\mathrm{H} 1$ & $\mathrm{TL} \longrightarrow \mathrm{LO}$ & 0.792 & 0.049 & $16.127^{* * *}$ & Supported \\
\hline $\mathrm{H} 2$ & $\mathrm{TL} \longrightarrow \mathrm{FI}$ & 0.513 & 0.044 & $11.585^{* * *}$ & Supported \\
\hline $\mathrm{H} 3$ & $\mathrm{TL} \longrightarrow \mathrm{LO} \longrightarrow \mathrm{FP}$ & 0.156 & 0.039 & $3.956^{* * *}$ & Supported \\
\hline $\mathrm{H} 4$ & $\mathrm{TL} \longrightarrow \mathrm{FI} \longrightarrow \mathrm{FP}$ & 0.751 & 0.052 & $14.535^{* * *}$ & Supported \\
\hline
\end{tabular}

${ }^{* * *} p<0.001,{ }^{* *} p<0.01$.

In summary, the transformational leadership of the learning orientation, firm innovativeness, and the financial performance as hypothesized. As a result, the model used for measurement can be applied using structural equation model measurement to analyze future causal influence. Table 3 Statistics from fitting evaluation of the transformational leadership, learning orientation, firm innovativeness, and financial performance in research. The overall direct and indirect effects related to the transformational leadership of learning orientation influencing the financial performance, transformational leadership of firm innovativeness influencing the financial performance are expressed in Table 4. As revealed in Figure 2 and Table 4, suggest that transformational leadership has a positive effect on learning orientation $(\beta=0.792, p<0.001)$. Hence, hypothesis 1 is supported. Similarly, transformational leadership has a positive effect on firm innovativeness $(\beta=0.513, p<0.001)$. Thus, hypothesis 2 is supported. This result demonstrates that transformational leadership has a positive indirect effect on financial performance through the mediation of learning orientation $(\beta=0.156, p<0.001)$. Hence, hypothesis 3 is supported. The results indicate transformational leadership has a positive indirect effect on financial performance through the mediation of firm innovativeness $(\beta=0.751, \mathrm{p}<$ 0.001). Thus, hypothesis 4 is supported.

\section{Conclusions}

The results of present research recommend that transformational leadership have a positive effect on learning orientation. The outcomes direct that transformational leadership have a positive influence on firm innovativeness. 
Consistent with Rusliati et al. (2020), which suggests that leadership will successfully effect business development when sustained by several characteristics, such as manage the business, capture opportunities, personal integrity, and communication. Besides, leadership and organizational culture of employees must to be improved to increase job satisfaction (Paais \& Pattiruhu, 2020). Business innovativeness as introducing innovations novel to the business, whether the innovation is expressed in goods, procedures, and administration or advertising strategies (Weerawardena, O'Cass, \& Julian, 2006). Leadership has influence on employee performance, job satisfaction, and work motivation (Pancasila et al., 2020). Transformational leadership that persons inside the firm are inspired to absorb and more accessible to novel information. Additionally, innovative firms frequently approve cross-functional players (Kuratko et al., 2001) quite than outdated severe and graded structures, to enable infrastructures that, in turn, take round an organization-wide agreement of areas and instructions. Therefore, innovative firms inculcate ideals of promise to learning, open-mindedness, and shared vision.

This empirical evidence implies that transformational leadership has affected financial performance. This study shows the moderating effect of firm innovativeness. Considering this, financial success has affected transformational leadership. This work also shows the moderating effect of learning orientation. This conclusion is consistent by Weerawardena et al. (2006); Liao et al. (2008), which suggests that the additional creative leadership, the extra innovation in the organization. Consequently, this research promotes learning orientation to improve innovation within the organization, including organizations and leaders among themselves. Instead of learning inertia by a productive, novel method, organizations and leaders can learn. If the direction of thinking should affect financial performance positively (Liao, Fei \& Liu, 2008). According to García-Morales et al. (2008), transformational leadership has remained create to have an important influence on learning orientation and firm innovativeness. Similarly, in the education done by Bakar and Mahmood (2014), learning orientation was found to partially mediate the association among transformational leadership and financial performance. Such effects were nevertheless reliable through folks reported through (Calantone et al., 2002). They revealed innovation in business as a crucial factor for financial success. These finding on firm creativity often suggest that the indirect effects of transformation leadership on financial output that depend on the context of the study. Such findings also match prior literature (Calantone et al., 2002; Damanpour et al., 1989; Deshpandé \& Farley, 2004; Narver \& Slater, 1990; Rhee et al., 2010).
This can be difficult for companies to be creative though. In particular, product and process advancement can involve substantial investments. However, in some cases, companies will face a time delay between the innovation and the gains it creates. Besides, being innovative involves risk, and there is no guarantee of success. For instance, Jenssen (2003) initiate that it is regularly the adopter and not the stable that generates the innovation that accepts the assistances. However, the association among firm innovativeness and financial performance was important and positive, and this demonstrations that businesses in the small and medium-sized enterprises (SMEs) in Thailand can gain from being innovative. This empirical evidence implies that transformational leadership has affected financial performance. This is reliable through our estimate and concept; although transformative leadership generates a productive inside situation and extends the latitude for learning orientation to ensue, to have a positive influence on performance, the vision of leadership in medium to large companies must be effectively shared among all members of the organization (Harrison \& Leitch, 2005). Transformational leadership will be used to assess financial performance. For instance, elements are revenue income, sales growth rates, and overall profitability. The products will be assessed increased financial performance.

\section{Limitations}

There are drawbacks to research like other studies. It is a cross-sectional analysis that explores a given opinion in time. Deprived of longitudinal data, assumptions concerning destiny cannot be strained. Generalize companies that had left the commercial were not comprised in the sample, and the results obtainable in this object can solitary for enduring companies. It is an essential limitation to be considered, specifically when firm innovation and financial performance are primary topics here, though researchers change in their views on how these two aspects impact firms ended time. Besides, one subjective methods were used to evaluate financial performance. While this is a standard approach for assessing financial performance, and while earlier trainings have exposed clear linkages among subjective and quantitative financial performance indicators (Dess \& Robinson Jr, 1984), this dimension of research is often perceived as one of its drawbacks. Several types of research mixed subjective and objective measurements (Aragón-Correa et al., 2005), and others used one objective procedures (Jenssen, 2003). While most researchers establish a relationship between firm innovation and financial performance when companies consider themselves efficient when using quantitative measurements Jenssen (2003), found no evidence of this connection. Ultimately, similar research to the current one expending an empirical degree of financial performance may 
give additional legitimacy to the conclusions reached on the relations among transition leadership, learning focus, firm innovation, and financial performance.

\section{References}

Aaker, D. A., Kumar, V., \& Day, G. S. (2001). Marketing Research. New York, NY: John Wiley and Sons.

Adler, D., (2015). Doppelte Hegemonie. Monograph. https://doi. org/10.5771/9783845265742.

Akgun, A. E., Keskin, H., Byrne, J. C., \& Aren, S. (2007). Emotional and learning capability and their impact on product innovativeness and firm performance. Technovation, 27(9), 501-513. https://doi.org/10.1016/j.te chnovation.2007.03.001.

Ali, S. H. K., Khan, N. S., \& Yildiz, Y (2020). Leadership effects on CSR employee, media, customer, and NGOs. Management and Economics Research Journal, 6(1), 1-9. https://doi. org/10.18639/merj.2020.961566.

Amabile, T. M. (1996). Creativity in context. Boulder, CO: Westview Press.

Aragon-Correa, J. A., \& Cordon-Pozo, E. (2005). The influence of strategic dimensions and the environment on the introduction of internet as innovation into small and medium-sized enterprises. Technology Analysis \& Strategic Management, 17(2), 205-218. https://doi.org/10.1080/09537320500088856.

Aragon-Correa, J. A., Garcia-Morales, V. J., \& Cordon-Pozo, E. (2007). Leadership and organizational learning's role on innovation and performance: lessons from Spain. Industrial Marketing Management, 36(3), 349-359. https://doi. org/10.1016/j.indmarMan.2005.09.006.

Armstrong, J. S., \& Overton, T. S. (1977). Estimating non-response bias in mail surveys. Journal of Marketing Research, 14(3), 396. https://doi.org/10.2307/3150783.

Argyris, C., \& Schon, D. A. (1978). Organizational learning: a theory of action perspective. Reading, Mass: AddisonWesley. Organization Studies, 1(3), 292-293. https://doi. org/10.1177/017084068000100310.

Arendt, L. (2009). Transformational leadership and follower creativity: the moderating effect of leader humor. Review of Business Research, 9(4), 100-106.

Avlonitis, G. J., Kouremenos, A., \& Tzokas, N. (1994). Assessing the innovativeness of organizations and its antecedents: project innovstrat. European Journal of Marketing, 28(11), 5-28. https://doi.org/10.1108/03090569410075812.

Avolio, B. J., \& Bass, B. M. (1995). Individual consideration viewed at multiple levels of analysis: a multi-level framework for examining the diffusion of transformational leadership. The Leadership Quarterly, 6(2), 199-218. https://doi. org/10.1016/1048-9843 (95)90035-7.

Avolio, B. J., \& Bass, B. M. (1988). Transformational leadership, charisma and beyond. In: J. G. Hunt, B. R. Baliga, H. P. Dachler,
\& C. A. Schriesheim (Eds.), International leadership symposia series. Emerging leadership vistas, 29-49.

Avolio, B. J., \& Gardner, W. L. (2005). Authentic leadership development: getting to the root of positive forms of leadership. The Leadership Quarterly, 16(3), 315-338. https://doi. org/10.1016/j.leaqua.2005.03.001

Bakar, M. S., \& Mahmood, R. (2014). Linking transformational leadership and corporate entrepreneurship to performance in the public higher education institutions in Malaysia. Advances in Management and Applied Economics, 4(3), 109-122.

Barney, J. (1991). Firm resources and sustained competitive advantage. Journal of Management, 17(1), 99- 120. https://doi. org/10.1177/014920639101700108.

Bass, B. M. \& Riggio, R.E. (2006). Transformational leadership (2nd ed). Lawrence erlbaum associates publishers.

Bass, B. M., Avolio, B. J., Jung, D. I., Berson, Y. (2003). Predicting unit performance by assessing transformational and transactional leadership. Journal of Applied Psychology, 88(2), 207-218.

Bass, B. M. (1985). Leadership and performance beyond expectations. New York: The Free Press.

Bass, B. M. (1999). Two decades of research and development in transformational leadership. European Journal of Work and Organizational Psychology, 8(1), 9-32. https://doi. org/10.1080/135943299398410.

Burns, J. M. (1978). Leadership. New York. Harper \& Row.

Budur, T. (2018). The impact of Al-Ghazali's virtues on organizational commitment and performance: A case study at private education institutions in Kurdistan region of Iraq. Icabep. In: ICABEP 2019 Conference Proceedings. https://doi. org/10.23918/icabep2019p18.

Budur, T. (2018). Analytic hierarchy process to evaluate corporate image, trust, and switching cost of GSM operators: A case of Kurdistan Region of Iraq. International Journal of Social Sciences \& Educational Studies, 5(2), 241-250. https://doi. org/10.23918/ijsses.v512p241.

Budur, T., Faraj, K. M., \& Karim, L. A. (2019). Benchmarking operations strategies via hybrid model: A case study of caférestaurant sector. Amazonia Investiga, 8(23), 842-854.

Blanchard, K. H., Zigarmi, D., \& Nelson, R. B. (1993). Situational leadership ${ }^{\circledR}$ after 25 years: a retrospective. Journal of Leadership \& Organizational Studies, 1(1), 21-36. https://doi. org/10.1177/107179199300100104.

Bettis, R. A., \& Prahalad, C. K. (1995). The dominant logic: retrospective and extension, Strategic Management Journal, 16(1), 5 -14. https://doi.org/10.1002/smj.4250160104.

Bono, J. E., \& Judge, T. A. (2004). Personality and transformational and transactional leadership: a meta-analysis. Journal of Applied Psychology, 89(5). 901-910. https://doi. org/10.1037/0021-9010.89.5.901. 
Bono, J. E., \& Judge, T. A. (2003). Self-concordance at work: toward understanding the motivational effects of transformational leaders. Academy of Management Journal, 46(5), 554-571. https://doi.org/10.2307/30040649.

Calantone, R. J., Cavusgil, S. T., \& Zhao, Y. (2002). Learning orientation, firm innovation capability, and firm performance. Industrial Marketing Management, 31(6), 515-524. https://doi. org/10.1016/s0019-8501(01)00203-6.

Damanpour, F. (1991). Organizational innovation: a metaanalysis of effects of determinants and moderators. Academy of Management Journal, 34(3), 555-590. https://doi. org/10.5465/256406.

Damanpour, F., Szabat, K. A., \& Evan, W. M. (1989). The relationship between types of innovation and organizational performance. Journal of Management Studies, 26(6), 587-601. https://doi.org/10.1111/j.1467-6486.1989.tb00746.x.

Das, S. C. (2017). Managing and leading change through transformational leadership: managing and leading change through transformational leadership.

De Geus, A. P. (1988). Planning as learning. Harvard Business Review, 66(2).70-74.

Demir, A., \& Budur, T. (2019). Roles of leadership styles in corporate social responsibility to non-governmental organizations (NGOs). International Journal of Social Sciences \& Educational Studies, 5(4), 174-183. https://doi.org/10.23918/ ijsses.v5i4p174.

Dess, G. G., \& Robinson Jr, R. B. (1984). Measuring organizational performance in the absence of objective measures: the case of the privately held firm and conglomerate business unit. Strategic Management Journal, 5(3), 265-273. https://oi. org/10.1002/smj.4250050306.

Deshpande, R., Farley, J. U., \& Webster, F. E. (1993). Corporate culture, customer orientation, and innovativeness in Japanese firms: A Quadrat analysis. Journal of Marketing, 57(1), 23-37. https://doi.org/10.1177/002224299305700102.

Deshpande, R., \& Farley, J. U. (2004). Organizational culture, market orientation, innovativeness, and firm performance: an international research odyssey. International Journal of Research in Marketing, 21(1), 3-22. https://doi.org/10.1016/j. ijresmar.2003.04.002.

Dvir, T., Eden, D., Avolio, B. J., \& Shamir, B. (2002). Impact of transformational leadership on follower development and performance: a field experiment. Academy of Management Journal, 45(4), 735-744. https://doi.org/10.2307/3069307.

Diamantopoulos, A., \& Siguaw, J. (2000). Introduction to LISREL: a guide for the uninitiated. London, UK: SAGE Publications. Inc. https://doi.org/10.4135/9781849209359.

Dyer, J.H., \& Singh H., (1998). The relational view: cooperative strategy and sources of interorganizational competitive advantage. Academy of Management Review, 23(4), 660-679. https://doi.org/10.5465/amr.1998.1255632.

Flanigan, R., Bishop, B., Brachle, B., \& Winn, B. (2017). Leadership and small firm performance: the moderating effects of demographic characteristics. Creighton Journal of Interdisciplinary Leadership, 3(1), 2-19. https://doi. org/10.17062/cjil.v3il.54.

Galer, G., \& Van der Heijden. (1992). The learning organization: How planning creates organizational learning. Marketing and Intelligence \& Planning, 10(6), 5-12. https://doi. org/10.1108/02634509210018702.

Garcia, V. J., Llorens, F. J., \& Verdu, A. J. (2007). Influence of personal mastery on organizational performance through organizational learning and innovation in large firms and SMEs. Technovation, 27(9), 547-568. https:doi.org/10.1016/j. tecHnovation.2007.02.013.

Garcia-Morales, V. J., Llorens-Montes, F. J., \& Verdu-Jover, A. J. (2008). The effects of transformational leadership on organizational performance through knowledge and innovation. British Journal of Management, 19(4), 299-319. https:// doiorg/10.1111/j.1467-8551.2007.00547.x.

Geh, E. Z. (2014). Organizational spiritual leadership of worlds "made" and "found". Leadership \& Organization Development Journal, 35(2).137-151. https://doi.org/10.1108/LODJ-042012-0052.

Hair, J. F., Black, W. C., Babin, B. J., \& Anderson, R. E. (2010). Multivariate data analysis: a global perspective $\left(7^{\text {th }}\right.$ ed.). Upper Saddle River, NJ: Pearson Prentice Hall.

Harrison, R.T., \& Leitch, C.M. (2005). Maximising the potential of University Spin-Outs: the development of second-order commercialization activities. $R$ and D Management, 35(3), 247-272. https://doi.org/10.1111/j.1467-9310.2005.00388. x.

Huber, G. P. (1991). Organizational learning: the contributing processes and the literatures. Organization Science, 2(1), 88115. https://doi.org/10.1287/orsc.2.1.88.

Hurley, R. F., \& Hult, G. T. M. (1998). Innovation, market orientation and organizational learning: an integration and empirical examination. Journal of Marketing, 62(3), 42-54. https://doi.org/10.1177/002224299806200303.

Hult, G. T. M., \& Ferrell, O. C. (1997). Global learning capacity in Purchasing: Construct and Measurement. Journal of Business Research, 40(2), 97-111. https://doi.org/10.1016/s01482963(96)00232-9.

Hult, G. T. M. (1998). Managing the international strategic sourcing process as a market driven organizational learning system. Decision Science, 29(1), 193-216. https://doi.org/10.1111/ j.1540-5915.1998.t b01349.x.

Hult, G. T. M., Hurley, R. F., \& Knight, G A. (2004). Innovativeness: its antecedents and impact on business performance. Industrial Marketing Management, 33(5), 429-438. https://doi. org/10.1016/j.indmarman.2003.08.015.

Jain, P. (2015). The role of transformational leadership in organizational commitment. International Journal of Business Quantitative Economics and Applied Management Research, 2(5), 1-11.

Janssen, O., \& Yperen, N.W.V. (2004). Employees' goal orientation, the quality of leader-member exchange, and the outcomes of 
job performance and job satisfaction. Academy of Management Journal, 47(4). 368-384. https://doi.org/10.5465/20159587.

Jenssen, J. I. (2003). Innovation, capabilities, and competitive advantage in Norwegian shipping. Maritime Policy and Management. An International Journal of Shipping and Port Research, 30(2), 93-106. https://doi. org/10.1080/0308883032000084841.

Joo, B., \& Lim, T. (2009). The effects of organizational learning culture, perceived job complexity and proactive personality on organizational commitment and intrinsic motivation. Journal of Leadership \& Organizational Studies, 16(1), 48-60. https://doi. org/10.1177/1548051809334195.

Jung, D. I., Chow, C., \& Wu, A. (2003). The role of transformational leadership in enhancing organizational innovation: hypotheses and some preliminary findings. The Leadership Quarterly, 14(4-5), 525-544. https://doi.org/10.1016/s10489843(03)00050-x.

Kang, W., \& Montoya, M. (2014). The impact of product portfolio strategy on financial performance: the roles of product development and market entry decisions. Journal of Product Innovation Management, 31(3), 516-534. https://doi. org/10.12111.

Kaya, N., \& Patton, J. (2011). The effects of knowledge-based resources, market orientation and learning orientation on innovation performance: an empirical study of Turkish firms. Journal of International Development, 23(2), 204-219. https:// doi.org/10.1002/jid.1662.

Kelloway, E. K. (2015). Using Mplus for Structural Equation Modeling; AResearcher's Guide. (2nd ed.). Thousand Oaks, CA: Sage Publications. https://doi.org/10.4135/9781483381664.

Kirkbride, P., \& Kirkbride, P. (2006). Developing transformational leaders: the full range leadership model in action. Industrial and Commercial Training, 38(1), 23-32. https://doi. org/10.1108/00197850610646016.

Knowles, C., Hansen, E. N., \& Dibrell, C. (2008). Measuring firm innovativeness: development and refinement of a new scale. Journal of Forest Products Business Research, 5(5), 1-25.

Kohli, A. K., Shervani, T. A., \& Challagalla, G. N. (1998). Learning and performance orientation of salespeople: the role of supervisors. Journal of Marketing Research, 35(3). 263-274. https://doi.org/10.1177/002224379803500211.

Kouzes, J. M., \& Posner, B. Z. (2006). The leadership challenge. (3rd ed.). Hoboken, NJ: John Wiley \& Sons.

Kovach, J. J., Hora, M., Manikas, A., \& Patel, P. C. (2015). Firm performance in dynamic environments: the role of operational slack and operational scope. Journal of Operations Management, 37(1), 1-12. https://doi.org/10.1016/j.jom. 2015.04.002.

Kuratko, D. F., Ireland, R. D., \& Hornsby, J. S. (2001). Improving firm performance through entrepreneurial actions: Acordia's corporate entrepreneurship strategy. Academy of Management Executive, 15(4), 60-71. https://doi.org/10.5465/ ame.2001.5897658.
Lee, J. Y., \& Lee, Y. (2018). Job crafting and performance: literature review and implications for human resource development. Human Resource Development Review, 17(3), 277-313. https:// doi.org/10.1177/1534484318788269.

Liao, S.H., Fei, W.C., \& Liu, C.T. (2008). Relationships between knowledge inertia, organizational learning and organization innovation. Technovation, 28(4), 183-195. https://doi. org/10.1016/j.technovation.2007.11.005.

Lim, B., \& Ployhart, R. E. (2004). Transformational leadership: relations to the five-factor model and team performance in typical and maximum contexts. Journal of Applied Psychology, 89(4), 610-621. https://doi.org/10.1037/0021-9010.89.4.610.

Llorens Montes, F. J., Ruiz Moreno, A., \& Garcia Morales, V. (2005). Influence of support leadership and teamwork cohesion on organizational learning, innovation and performance: an empirical examination. Technovation, 25(10), 1159-1172. https://doi.org/10.1016/j.technovation.2004.05.002.

Lonial, S. C., \& Carter, R. E. (2015). The impact of organizational orientations on medium and small firm performance: a resource-based perspective. Journal of Small Business, 53(1), 94-113.https://doi.org/10.1111/jsbm.12054.

McMurray, A. J., Islam, M. M., Sarros, J. C., \& Pirola-Merlo, A. (2013). Workplace innovation in a nonprofit organization. Nonprofit Management and Leadership, 23(3), 367-388. https://doi.org/10.1002/nm 1.21066.

Metwally, A. H., \& El-bishbishy, N. (2014). The impact of transformational leadership style on employee satisfaction. The Business \& Management Review, 5(3), 3-4.

Mohammed, S. S., Suleyman, C., \& Taylan, B. (2020). Burnout determinants and consequences among University Lecturers. Revista Amazonia Investiga, 9(27), 13-24. https://doi. org/10.34069/ai2020.27.03.2.

Mughal, M., Bahaudin, A., \& Salleh, N. (2019). Behavioral factors for IT project success in Pakistan: moderating effect of leadership styles. Management Science Letters, 9(7), 987-996. https://doi.org/10.5267/j.msl.2019.4.006.

Narver, J. C., \& Slater, S. F. (1990). The effect of a market orientation on business profitability. Journal of Marketing, 54(4), 20-36. https://doi.org/10.2307/1251757.

Neter, J., Wasserman, W., \& Kutner, M. H. (1985). Applied linear statistical models: regression, analysis of variance, and experimental designs (2nd ed.). Homewood, IL: Richard D. Irwin.

Nunnally, J. C., \& Bernstein, I. H. (1994). Psychometric theory. New York, NY: McGraw-Hill.

Paais, M., \& Pattiruhu, R. J. (2020). Effect of motivation, leadership, and organizational culture on satisfaction and employee performance. Journal of Asian Finance, Economics and Business, 7(8), 577-588. doi:10.13106/jafeb.2020.vol7. no8.577.

Pancasila, I., Haryono, S., \& Sulistyo, B. A. (2020). Effects of Work Motivation and Leadership toward Work Satisfaction and Employee Performance: Evidence from Indonesia. Journal 
of Asian Finance, Economics and Business, 7(6), 387-397. doi:10.13106/jafeb.2020.vol7.no6.387.

Parast, M. M., Golmohammadi, D., Mcfadden, K. L., \& Miller, J. W. (2015). Linking business strategy to service failures and financial performance: empirical evidence from the US domestic airline industry, Journal of Operations Management, 38(1), 14-24. https://doi.org/10.1016/j.jom.2015.06.003.

Phipps, S. T. A., Prieto, L. C., \& Verma, S. (2012). Holding the helm: exploring the influence of transformational leadership on group creativity and the moderating role of organizational learning culture. Journal of Organizational Culture, Communication and Conflict, 16(2), 145-156.

Purushothaman, A. (2015). Organizational learning: a road map to evaluate learning outcomes in knowledge intensive firms. Development and Learning in Organizations: An International Journal, 29(3), 11-14. https://doi.org/10.1108/dlo-07-20140053.

Rasool, H. F., Arfeen, I. U., Mothi, W., \& Aslam. (2015). Leadership styles and its impact on employees' performance in health sector of Pakistan, City University Research Journal, 5(1), $97-$ 109. https://doi.org/10.1108/tg-11-2014-0054.

Rhee, J., Park, T., \& Lee, D. H. (2010). Drivers of innovativeness and performance for innovative SMEs in South Korea: mediation of learning orientation. Technovation, 30(1), 65-75. https://doi.org/10.1016/j.technovation.2009.04.008.

Rusliati, E., Mulyaningru, M., Wibowo, A., \& Narmaditya, B. S. (2020). Does entrepreneurial leadership matter for microenterprise development? : lesson from west java in Indonesia. Journal of Asian Finance, Economics and Business, 7(8), 445-450. doi:10.13106/jafeb.2020.vol7.no8.445.

Sarros, J. C., \& Santora, J. C. (1995). The transformationaltransactional leadership model in practice. Leadership \& Organization Development Journal, 22(8), 383-393. https:// doi.org/10.1108/01437730110410107.

Schumacker \& Lomax. (1996). A beginner's guide to structural equation modeling. Lawrence Erlbaum Associates, Inc.

Schumacker, R. E., \& Lomax, R. G. (2010). A beginner's guide to structural equation modeling (3rd ed.). Mahwah, NJ: Lawrence Erlbaum Associates.

Seda Mengu. (2015). Violence and social media. Athens Journal of Mass Media and Communications, 1(3), 211-228. https://doi. org/10.30958/ajmmc.1-3-4.

Sinkula, J. M., Baker, W. E., \& Noordewier, T. (1997). A framework for market-based organizational learning: linking values, knowledge, and behavior. Journal of the Academy of Marketing Science, 25(4), 305-318. https://doi. org/10.1177/0092070397254003.
Small and Medium-sized Enterprise. (2020).The office of small and medium enterprises. Retrieved January 28, 2020, from https:/ www. sme.go.th/th/.

Sosik, J. J., Kahai, S. S., \& Avolio, B. J. (1998). Transformational leadership and dimensions of creativity: motivating idea generation in computer-mediated groups. Creativity Research Journal, 11(2), 111-121. https://doi.org/10.1207/ s15326934crj1102_3.

Sujan, H., Weitz, B. A., \& Kumar, N. (1994). Learning orientation, working smart and effective selling. Journal of Marketing, 58(3), 39-52. https://doi.org/10.2307/1252309.

Tajeddini, K. (2015). Using the integration of disparate antecedents to drive world - class innovation performance: an empirical investigation of Swiss watch manufacturing firms. Review of Applied Management Studies, 13(1), 34-50. https://doi. org/10.1016/j.tekhne.2015.09.001.

Torlak, N. G., Demir, A., \& Budur, T. (2019). Impact of operations management strategies on customer satisfaction and behavioral intentions at café-restaurants. International Journal of Productivity and performance Management. https://doi. org/10.1108/IJPPM-01-2019-0001.

Wang C. L., \& Ahmed, P. K. (2004). The development and validation of the organizational innovativeness construct using confirmatory factor analysis. European Journal of Innovation Management, 7(4), 303-313. https://doi. org/10.1108/14601060410565056.

Weerawardena, J., O'Cass, A., \& Julian, C. (2006). Does industry matter? Examining the role of industry structure and organizational learning in innovation and brand performance, Journal of Business Research, 59(1), 37-45. https://doi. org/10.1016/j.jbusres.2005.02.004.

Westerfield, R. J. (2003). Fundamentals of Corporate Finance. New York, NY: McGraw Hill.

Wiratchai, N. (1999). LISREL model: inferential statistics for research (3rd ed.). Bangkok, Thailand: Chulalongkorn University Printing House.

Yoon, W., Song, H., Lim, H., \& Joo, K. (2010). Structural determinants of team performance: the mutual influences of learning culture, creativity, and knowledge. Human Resource Development International, 13(3), 249-264. https://doi.org/10 $.1080 / 13678868.2010 .483815$.

Yukl, G. (1999). An evaluation of conceptual weaknesses in transformational and charismatic leadership theories. The Leadership Quarterly, 10(2), 285-305. https://doi.org/10.1016/ s1048-9843(99)00013-2. 